\title{
Characterization of Local Trichoderma spp. as Potential Bio-Control Agents, Screening of in vitro Antagonistic Activities and Fungicide Tolerance
}

\author{
Potansiyel Biyokontrol Ajanları Olarak Yerel Trichoderma spp. \\ Türlerinin Karakterizasyonu, in vitro Antagonistik Aktivitelerinin \\ ve Fungisit Toleransların Incelenmesi
}

Research Article

Sengul Alpay Karaoglu*, Arif Bozdeveci, Necla Pehlivan*

Recep Tayyip Erdogan University, Deparment of Biology, Rize, Turkey.

\begin{abstract}
A B S T R AC T
- nlightening effects of biocontrol agents as Trichoderma spp. to provide disease control by combating pat- hogens is an important alternative in agricultural crop production. To that end, 9 species of Hypocrea/ Trichoderma having green ascospores isolated from the soil that tea plants cultivated in are identified by ITS sequences and were found to be close relative of Trichoderma sect. Pachybasium (77\%). Ethyl acetate extracts of fungal isolates exhibited the antimicrobial activity against to Vibrio sp, Serratia marcescens, Mycobacterium smegmatis and Bacillus cereus but no antifungal activity was detected. The highest level of inhibitory activity was observed against to M. smegmatis by Trichoderma harzianum ID4A, ID4B and ID6B. In dual culture test, all Trichoderma strains were found to be showing the highest inhibitory activity against to the plant pathogens Botrytis cinerea, Sclerotonia sclerotiorum and Rhizoctonia solani (AG3), but relatively low activity against to the entomopathogen fungi. Volatile metabolites of Trichoderma spp. caused maximum reduction in mycelial growth and sclerotial production. Tested strains showed the highest tolerance to the fungicide Dikozin, whereas the lowest tolerance was against to the Captan regardless of the dosage.
\end{abstract}

\section{Key Words}

Trichoderma, bio-control agent, Antimicrobial activity, Fungicide.

\section{öz}

\begin{abstract}
Trichoderma spp. gibi biyokontrol ajanlarının etkilerini incelemek tarımsal üretimde patojenlerle mücadele yoluyla hastalık kontrolünü sağlamada önemli bir alternatiftir. Bu amaçla, çay bitkilerinin topraklarından izole edilmiş yeşil askosporlara sahip 9 Hypocrea/ Trichoderma türü, ITS sekansları ile tanımlanmış ve türlerin \% 77 oranında Trichoderma sect. Pachybasium ile yakın akraba olduğu belirlenmiştir. Fungal izolatların etil asetat ekstraktlarının, Vibrio sp., Serratia marcescens, Mycobacterium smegmatis ve Bacillus cereus'a karşı antimikrobiyal aktivite sergilediği tespit edilmesine karşın, izolatlarda antifungal aktivite gözlenmemiştir. En yüksek inhibisyon aktivitesinin, Trichoderma harzianum ID4A, ID4B ve ID6B tarafından M. smegmatis'e karşı oluşturulduğu ortaya çıkarılmıştır. Çift kültür testinde, tüm Trichoderma suşlarının Botrytis cinerea, Sclerotonia sclerotiorum ve Rhizoctonia solani (AG3) bitki patojenlerine karşı en yüksek inhibitör aktivite gösterdiği, fakat entomopatojen mantarlara karşı nispeten düşük etkide oldukları bulunmuştur. Trichoderma spp. uçucu metabolitleri, misel artışı ve sklerotik üretimde maksimum azalmaya neden olmuştur. Test edilen suşların, dozajdan bağımsız olarak en yüksek toleransı Dikozin fungisitine karşı, en düşük toleransı ise; Captan'a karşı gösterdiği belirlenmiştir.
\end{abstract}

\section{Anahtar Kelimeler}

Trichoderma, biyokontrol ajanı, antimikrobiyal aktivite, fungisit.

Article History: Received: Sep 11, 2017; Oct 18: XX, 2017; Accepted: Jan 11, 2018; Available Online: Mar 26, 2018.

DOI: 10.15671/HJBC.2018.233

Correspondence to: N. Pehlivan, Sengul Alpay Karaoglu, Recep Tayyip Erdogan University, Deparment of Biology, Rize, Turkey. 


\section{INTRODUCTION}

Trich richoderma is one of the most common fungal biocontrol agents in agriculture for the management of plant diseases caused by an extensive spectrum of fungal pathogens [1]. Some studies showed that several strain of Trichoderma had significant remedial effect on plant diseases caused by pathogens such as Botrytis cinerea Fusarium oxysporum, F. culmorum, F. moniliforme, Sclerotium rolfsii, Sclerotium sclerotonia, Rhizoctonia solani and Aspergillus flavus [2].

Trichoderma spp. are primarily present in all agricultural soils including decaying wood. In the past studies, nine species were distinguished based on the morphological features according to Rifai [3]. This first classification has been considered preliminary, since some aggregates formed among morphologically indistinguishable species and have made identification harder [4]. Consistent results have been obtained through the sequence analyses of ITS1, ITS2, and of genes such as $\beta$-tubulin and hydrophobin or all combined [5]. Major mechanism involved in the biocontrol activity of Trichoderma spp. is the ability of competition for space and nutrients in the rhizosphere flora, production of diffusible and/or volatile antibiotics, prevention of abiotic stresses such as salt, heat and drought and finally mycoparasitism [6].

Trichodermin was a secondary metabolite isolated from the fermented broth of $T$. harzianum and showed antifungal activity against mycelial growth of phytopathogenic fungi, such as Botrytis cinerea. In contrast to other fungi, Trichoderma spp. has been reported to have limited applications in biocontrol of pathogenic bacteria [7]. In addition, it has been reported that Trichoderma spp. is able to produce antibacterial compounds that act against human-pathogenic bacteria such as E. coli, S. aerus, K. pneumoniae [8].

The combined use of biocontrol agents and chemical pesticides has attracted much attention by either farmers or producers in order to obtain synergestic or additive effects in the control of soilborne diseases up to now [9]. Trichoderma spp. strains with greater biocontrol efficiency also have better tolerance against to pesticides to be used as major component in Integrated Pest Management
(IPM). To date, fungicides and insecticides are extensively used by farmers to control insects, pests and diseases in agro-economically important crops such as cotton, rice, maize and tomato [10], however agriculture needs to be sustained by more cleaner and safer processes to pursue an eco-friendly approach. In this manner, identifying biocontrol agents and understanding the mechanisms underlying the antagonistic effects of Trichoderma spp. especially on plant pathogens are important in creating effective and safe bio-control strategies.

In the present study, we aimed to determine the physical properties of strains with molecular characterization and their culture effect and the biocontrol potential. In this regard, Trichoderma spp. isolated from the soil which indigenous tea plants cultivated in ikizdere, Rize, Turkey identified with molecular tools and the capabilities of strains such as sporulation properties under different growth temperatures, heat tolerance, antibacterial and antifungal activities and fungicide tolerance were examined.

\section{MATERIAL and METHODS}

\section{Culture Medium and Inoculum Development}

Trichoderma spp. strains formerly isolated from the indigenous tea cultivation area in Rize province of Turkey were used in this study [11]. Strains were stored in Recep Tayyip Erdogan University, Microbiology and Molecular Biology Laboratory culture collection unit for further use. Control strain T. harzianum KUENS 1585 was purchased by the Simbiyotek Company in Istanbul. Trichoderma spp. strains were grown on Potato Dextrose Agar (PDA) (Merck, Germany) for 7 days. Hyphae and spores gained from pure cultures were transfered into $500 \mathrm{~mL}$ flasks containing $100 \mathrm{~mL}$ of Malt Extract Broth and were shaken at $150 \mathrm{rpm}$ in a rotary shaker (GFL, Germany) at $28^{\circ} \mathrm{C}$ for 10 days. Mycelia were harvested by filtration, washed with distilled water and powdered in liquid nitrogen.

\section{DNA Extraction and PCR Amplification of Fungi}

Genomic DNA extraction was carried out using DNeasy Plant Mini Kit (Qiagen, Hilden, Germany). Primers ITS4 and ITS5 described by Kanematsu and Naito [12] were used to amplify the 5.8S 
rDNA gene with the ITS-1 and ITS-2 regions. PCR amplification of ITS1-5.8S-ITS2 genes of fungal isolates were performed with universal primers of ITS5 (5 -GGAAGTAAAAGTCGTAACAAGG3 ) as forward primer and ITS4 (5 -TCCTCCGCTTATTGATATGC-3) as reverse primer [13]. PCR amplifications were established in a total volume of $50 \mu \mathrm{L}$. The components of reaction were $5 \mu \mathrm{L}$ 10xTaq-DNA polymerase buffer, $200 \mu \mathrm{M}$ of dNTPs, $0.05 \mathrm{nmol}$ of the primer pairs, 2.5 unit Taq-DNA polymerase (Fermentase), and $0.05 \mu \mathrm{g}$ genomic DNA. After the primary denaturation at $95^{\circ} \mathrm{C}$ for $5 \mathrm{~min}, 95^{\circ} \mathrm{C}$ for $1 \mathrm{~min}$, $55^{\circ} \mathrm{C}$ for $55 \mathrm{~s}, 72^{\circ} \mathrm{C}$ for $2 \mathrm{~min}$, with an extension step at $72{ }^{\circ} \mathrm{C}$ for $10 \mathrm{~min}$ were operated with thirty-five cycles in thermocycler (Eppendorf, Germany). Separated PCR products on $1 \%$ agarose gel, visualized with ethidium bromide and photographed under UV light.

\section{Characterisation of physical properties}

Studies were performed based on the effects of temperature on the sporulation and mycelial growth. Optimum temperature for growth [14] and effect on volatile metabolite production of Trichoderma spp. strains were also investigated according to Keszler et al. [15]. Effect of temperatures $\left(15-32^{\circ} \mathrm{C}\right)$ on the linear hyphal growth of Trichoderma spp. strains were studied in vitro on PDA medium in $9 \mathrm{~cm}$ Petri plates for each temperature. A bit $(5 \mathrm{~mm})$ of pure culture of Trichoderma spp. strains were placed at the center of Petri plates, replicated thrice with the help of sterile cork borer. The inoculated Petri plates were kept at $15,20,24,28$ and $32^{\circ} \mathrm{C}$ in the incubator and daily observation on mycelial growth of Trichoderma spp. strains were recorded at every 24 hrs up to 15 days. Radial development after the first $48 \mathrm{~h}$ culture was taken into account. On the 4 th, 7 th and 15 th days of fungi cultures, the number of spores was determined. Spore suspensions were prepared by adding $15 \mathrm{ml}$ of sterile distilled water to mature (7th and 15th days) fungal colonies on PDA plates to dislodge the spores from the mycelium. The spores were counted using a heamocytometer (Neubauer, Germany) as mentioned before [14].

A $1 \times 107 \mathrm{cfu} \mathrm{mL}^{-1}$ spore suspension was prepared to determine the tolerance of Trichoderma spp. spores to different temperatures. The spor suspension was distributed to ependorfs ( $1 \mathrm{~mL})$ and each ependorf was exposed to heat in a heater for 15 min at $45,55,65$ and $75^{\circ} \mathrm{C}$. Subsequently, 100 $\mu \mathrm{L}$ was added to the surface of the DRBC agar and spreading was carried out by baguette. Incubation was allowed for 3 days at $28^{\circ} \mathrm{C}$ [22].

\section{In vitro Antagonistic Activity Assays}

In vitro antagonistic activities were tested against to plant (Sclerotonia sclerotiorum, Rhizoctonia solani (AG3), Botrytis cinerea), human (Aspergillus flavus, Aspergillus niger RSKK4017) and insect pathogens (Beauveria bassiana ARSEF 8664, Isaria fumosorosea ARSEF 8333, Metarhizium anisopliae ARSEF 8433). All fungi were revived and cultured on PDA at $28 \pm 1^{\circ} \mathrm{C}$ for seven days. The antagonistic activity of Trichoderma spp. strains were tested in vitro using $85 \mathrm{~mm}$ petri dishes containing $20 \mathrm{~mL}$ of PDA medium with $\mathrm{pH} 5.5$. Mycelial discs ( $5 \mathrm{~mm}$ in diameter) of S. sclerotium, $R$. solani, B. cinerea, $A$. flavus and $A$. niger were placed on one edge of a petri dish containing PDA, while mycelial discs of Trichoderma spp. strains were placed on the opposite edge of the plate. Control petries consisted of the individual cultures of the pathogen. Each dual culture (pathogen-antagonist) had three replicates under $28 \pm 1{ }^{\circ} \mathrm{C}$. After 4,7 and 14 days, the plates were evaluated for antagonistic activity of the strains, considering the ability of the microorganisms to reduce pathogen colony expansion. The equation for the percentage inhibition of radial growth (PIRG) applied as below:

$$
\% P I R G=\frac{R_{1}-R_{2}}{R_{1}} \times 100
$$

PIRG = Percentage inhibition of radial growth; $\mathrm{R} 1=$ Radial growth of control;

R2 = Radial growth of Trichoderma spp. in the presence of the antagonist

The production of volatile compounds from Trichoderma spp. were determined as follows; two Petri dishes containing PDA were individually inoculated with a disc of $\mathrm{S}$. sclerotium and Trichoderma spp. and bottom parts were adjusted and attached by tape. The control sets did not contain the Trichoderma spp. The plates were randomized and incubated at $28 \pm 2{ }^{\circ} \mathrm{C}$ for 7 days. 
The diameters of Sclerotonia sclerotium colony cultures were measured daily. Three replicate plates were set for each treatment [16].

\section{Antimicrobial Activity Tests}

Trichoderma spp. were cultivated and maintained on slants of PDA media for 7 days at $28 \pm 1^{\circ} \mathrm{C}$. Conidia were scrapped from mycelia which grown on slants and cultivated on potato dextrose broth (PDB) media. Conidial densities in the suspension were determined by using the hemocytometer under a light microscope. Fungal inoculum $\left(1 \times 10^{7}\right.$ spore $/ \mathrm{mL}$ ) of each strain was prepared by blending PDA-grown cultures of the fungus with sterile distilled water for 14 days. A spore suspension of each strain was $10^{7}$ spores inoculated in 250 $\mathrm{mL}$ flasks containing $50 \mathrm{~mL}$ of PDB incubated for 21 days at $28 \pm 1{ }^{\circ} \mathrm{C}$ [17]. Fermentation broth was filtered and extracted by $50 \mathrm{~mL} 100 \%$ ethyl acetate, agitated for $60 \mathrm{~min}$ and then centrifuged at $1500 \mathrm{~g}$ for $30 \mathrm{~min}$. After separating two phases, organic phase was collected and dried at $40^{\circ} \mathrm{C}$ under vacuum using a rotary evaporator. Extracts were dissolved in $1 \mathrm{~mL}$ of DMSO which was then used to screen for their antimicrobial activity by agar diffusion assay method.

All test microorganisms except for plant pathogen fungi obtained from Abant Izzet Baysal and Gaziosmanpasa University were obtained from the Hifzisihha Institute of Refik Saydam (Ankara, Turkey). The antimicrobial activities were evaluated against eight selected gram negative bacteria; Escherichia coli ATCC25922, Klebsiella pneumonia ATCC13883, Pseudomonas aeruginosa ATCC43288, Yersinia pseudotuberculosis ATCC911, five Gram positive bacteria; Bacillus cereus 709 ROMA, Staphylococcus aureus ATCC25923, Enterococcus faecalis ATCC29212, Bacillus subtilis ATCC6633, Listeria monocytogenes ATCC43251, an acid-fast bacterium; Mycobacterium smegmatis ATCC607, yeast like fungi; Candida albicans ATCC60193, Candida tropicalis ATCC13803 and Saccharomyces cerevisiae RSKK 251, two plant pathogenic fungi; Botryts cinerea, Rhizoctonia solani AG3 and a saprofit fungus; Aspergillus niger RSKK4017. Salmonella sp., Proteus vulgaris, Vibrio sp. and Serratia marcescens were clinically isolated strains.

Simple susceptibility screening test via agarwell diffusion method was used. Each bacterium was suspended in Mueller Hinton (MH) (Difco, Detroit, MI) broth, whereas target fungi were suspended in the yeast extract broth. The microorganisms were diluted approximately to $10^{6} \mathrm{cfu} \mathrm{mL}^{-1}$ with the aid of the McFarland 0.5 standard All fungi species were cultivated on PDA and M. smegmatis was cultivated on Brain Heart Infusion Agar (BHIA) (Difco, Detriot, $M I)$. Those were flood-inoculated onto the surface of MHA, BHIA and PDA and then air-dried. Fivemilimeter diameter wells were created from the agar cutting with a sterile cork-borer and $50 \mu \mathrm{L}$ of the Trichoderma spp. extracts were placed into the wells. Plates that consist bacteria incubated for 24-48 $\mathrm{h}$ at $35^{\circ} \mathrm{C}$, whereas the fungi plates were incubated for $3-5$ days at $28^{\circ} \mathrm{C}$. M. smegmatis was grown for 3 days on BHIA plates at $35^{\circ} \mathrm{C}$ [18]. Antimicrobial activity was evaluated by measuring inhibition zone against to the target microorganism. Streptomycin $(10 \mu \mathrm{g})$, ampicillin $(10 \mu \mathrm{g})$ and fluconazole $(5 \mu \mathrm{g})$ were standard drugs used in the experiment. Ethyl acetate and dimethyl sulfoxide were used as negative control.

\section{Assay of Fungucide Tolerance}

Fungicides used by farmers extensively were selected to assess their effect on the growth of the Trichoderma spp. isolates. To that end, Trichoderma spp. isolates were exposed to three fungicides; Captan, Dikozin and Cuprenax. Three different fungicides Dikozin (75\% Mancozeb), Captan (Captan M 50 WP) and Cuprenax (Cupper oxychloride) were added to PDA medium with a final concentration of 2.5, 5.0 and $10.0 \mathrm{mg} \mathrm{mL}^{-1}$. A mycelial block in $5 \mathrm{~mm}$ diameter from one week of Trichoderma spp. culture was cut and placed into the center of the plates. After 7 days, Trichoderma spp. mycelial radial growth zone were measured [19]. Calculations were conducted based on the formula for the percentage inhibition of radial growth (PIRG) in duplicate.

\section{RESULTS and DISCUSSION}

The identification were performed based on the macroscopic and microscopic properties of nine Trichoderma spp. strains formerly isolated from the soil which tea plants cultivated in 100-1000 meter high. A commercial strain was tested for its properties as control (T. harzianum KUEN 1585). Isolates of Trichoderma spp. were characterized based on their $700 \mathrm{bp}$ fragment of the ITS1-5.8S- 
Table 1. Examined Hypocrea and Trichoderma spp. isolates and GenBank accession numbers of target sequences.

\begin{tabular}{|c|c|c|c|c|}
\hline Strain no & \multicolumn{2}{|l|}{ Species } & \multicolumn{2}{|c|}{ Similarity } \\
\hline$(\%)$ & \multicolumn{4}{|c|}{ ITS 1- 5.8- ITS2 } \\
\hline \multicolumn{5}{|c|}{ Gen Bank. No } \\
\hline \multirow[t]{5}{*}{ ID4A } & \multicolumn{2}{|c|}{ Hypocrea lixii BHU 221} & $100 \%$ & JN604833.1 \\
\hline & \multicolumn{2}{|c|}{ Trichoderma harzianum A12 } & $99 \%$ & KC139308.1 \\
\hline & \multicolumn{2}{|c|}{ Hypocrea lixii BHU18 } & $99 \%$ & JN604835.1 \\
\hline & \multicolumn{2}{|c|}{ Hypocrea lixii BHU110 } & $99 \%$ & JN604836.1 \\
\hline & \multicolumn{2}{|c|}{ Hypocrea lixii BHU226 } & $99 \%$ & JN604834.1 \\
\hline \multirow[t]{5}{*}{ ID4B } & \multicolumn{2}{|c|}{ T. harzianum NBAll-Th13 } & $99 \%$ & JX644593.1 \\
\hline & \multicolumn{2}{|c|}{ Trichoderma harzianum T12 } & $99 \%$ & KC609759.1 \\
\hline & $\begin{array}{l}\text { Trichoderma } \\
\text { IBSD-T142 }\end{array}$ & harzianum & $99 \%$ & JX518931.1 \\
\hline & $\begin{array}{l}\text { Trichoderma } \\
\text { IBSD-T47 }\end{array}$ & harzianum & $99 \%$ & JX518904.1 \\
\hline & $\begin{array}{l}\text { Trichoderma } \\
\text { IBSD-T11 }\end{array}$ & harzianum & $99 \%$ & JX518894.1 \\
\hline \multirow[t]{5}{*}{ ID6B } & $\begin{array}{l}\text { Trichoderma } \\
\text { FUE15 }\end{array}$ & harzianum & $99 \%$ & KC200074.1 \\
\hline & $\begin{array}{l}\text { Trichoderma } \\
\text { T65-NI }\end{array}$ & harzianum & $99 \%$ & U78881.1 \\
\hline & \multicolumn{2}{|c|}{ Hypocrea lixii BHU51 } & $99 \%$ & JN618343.1 \\
\hline & \multicolumn{2}{|c|}{ Hypocrea lixii BHU159 } & $99 \%$ & JN618342.1 \\
\hline & \multicolumn{2}{|c|}{ Hypocrea lixii BHU166 } & $99 \%$ & JN618339.1 \\
\hline \multirow[t]{5}{*}{ ID7C } & $\begin{array}{l}\text { Trichoderma } \\
\text { NR6929 }\end{array}$ & harzianum & $98 \%$ & AF194011.1 \\
\hline & $\begin{array}{l}\text { Trichoderma } \\
2930\end{array}$ & harzianum & $98 \%$ & AJ224016.1 \\
\hline & \multicolumn{2}{|c|}{ Trichoderma harzianum A14 } & $98 \%$ & KC139307.1 \\
\hline & \multicolumn{2}{|c|}{ Hypocrea lixii ATCC 20847} & $98 \%$ & FJ545255.1 \\
\hline & \multicolumn{2}{|c|}{ Hypocrea lixii IB32E1 } & $98 \%$ & FN598939.1 \\
\hline
\end{tabular}

ITS2 gene. According to the cluster analysis based on the ITS sequence of the genomic rRNA gene of 10 potential biocontrol agents, most Trichoderma spp. isolates were found to be very similar to Trichoderma sect. Pachybasium (77\%), whereas the others were similar to Trichoderma sect. Trichoderma spp. section (Table 1). Three groups of similar isolates were identified by cluster analysis. Seven isolates were found identical to T. harzianum, one isolate to ID17E of T. hamatum and one to ID20G T. atroviride. According to the sequencing data, seven strains were found similar to T. harzianum (99\%), one strain is to T. hamatum (94\%) and a strain is to T. atroviride (97\%).

Factors in determining the survivals of certain fungi on natural environment are important. One of these factors is the growing ability at different temperatures. Growth properties of Trichoderma spp. strains at different temperatures $(2,4,10,15$, $20,24,28,32,37$ and $42^{\circ} \mathrm{C}$ ) were investigated and no growth was observed on the strains at 2 to 10 ${ }^{\circ} \mathrm{C}$. In addition to that, increasing the temperature above $37-42{ }^{\circ} \mathrm{C}$ inhibited mycelial growth (Table 
252 | S. Alpay Karaoglu et al. / Hacettepe J. Biol. \& Chem., 2018, 46 (2), 247-261

Table 1. Examined Hypocrea and Trichoderma spp. isolates and GenBank accession numbers of target sequences (continue).

\begin{tabular}{|c|c|c|c|}
\hline \multirow[t]{5}{*}{ ID9A } & $\begin{array}{l}\text { Trichoderma aureoviride } \\
\text { T77 }\end{array}$ & $100 \%$ & HQ596945.1 \\
\hline & aureoviride & $100 \%$ & HQ596942.1 \\
\hline & Hypocrea lixii JBSERB241 & $100 \%$ & EF191311.1 \\
\hline & Hypocrea lixii NMMX3008 & $99 \%$ & JQ040357.1 \\
\hline & $\begin{array}{l}\text { Trichoderma harzianum } \\
\text { GJS 05-93 }\end{array}$ & $99 \%$ & FJ442645.1 \\
\hline \multirow[t]{5}{*}{ ID11C } & $\begin{array}{l}\text { Hypocrea lixii } \\
222136\end{array}$ & $100 \%$ & JN942884.1 \\
\hline & $\begin{array}{l}\text { Trichoderma citrinoviride } \\
\text { T200 }\end{array}$ & $99 \%$ & HQ596983.1 \\
\hline & $\begin{array}{l}\text { Hypocrea lixii } \\
229959\end{array}$ & $99 \%$ & AY605733.1 \\
\hline & $\begin{array}{l}\text { Trichoderma harzianum } \\
\text { TR040 }\end{array}$ & $99 \%$ & AF443925.1 \\
\hline & $\begin{array}{l}\text { Trichoderma harzianum } \\
\text { GJS 92-61 }\end{array}$ & $99 \%$ & HQ608080.1 \\
\hline \multirow[t]{5}{*}{ ID11D } & Hypocrea lixii GJS 04-227 & $100 \%$ & FJ442266.1 \\
\hline & Hypocrea lixii GJS 91-138 & $100 \%$ & AF443917.1 \\
\hline & $\begin{array}{l}\text { Hypocrea } \\
\text { DAOM231402 }\end{array}$ & $99 \%$ & AY605732.1 \\
\hline & Hypocrea lixii JBT1244 & $99 \%$ & AY605741.1 \\
\hline & $\begin{array}{l}\text { Trichoderma harzianum } \\
\text { P134 }\end{array}$ & $99 \%$ & $J F 311950.1$ \\
\hline \multirow[t]{5}{*}{ ID17E } & T. hamatum HBJZ1001 & $94 \%$ & JQ040347.1 \\
\hline & T. hamatum CQJB2001 & $94 \%$ & JQ040344.1 \\
\hline & T. hamatum T090 & $94 \%$ & HQ608116.1 \\
\hline & T. hamatum DAOM237553 & $94 \%$ & EU280136.1 \\
\hline & T. hamatum GHJ-5 & $94 \%$ & GQ331987.1 \\
\hline \multirow[t]{5}{*}{ ID20G } & $\begin{array}{l}\text { Trichoderma atroviride } \\
\text { DR19 }\end{array}$ & $97 \%$ & KC311841.1 \\
\hline & $\begin{array}{l}\text { Trichoderma atroviride } \\
\text { EGE-K-65 }\end{array}$ & $97 \%$ & JX119037.1 \\
\hline & $\begin{array}{l}\text { Trichoderma atroviride } \\
\text { ATCC20476 }\end{array}$ & $97 \%$ & JQ745258.1 \\
\hline & Trichoderma atroviride T39 & $97 \%$ & FJ975597.1 \\
\hline & $\begin{array}{l}\text { Trichoderma atroviride } \\
\text { KUC5026 }\end{array}$ & $97 \%$ & GQ241294.1 \\
\hline \multirow[t]{5}{*}{ T.h1585 } & Hypocrea lixii T 22 & $99 \%$ & GU570562.1 \\
\hline & Hypocrea lixii BHU199 & $99 \%$ & JN618342.1 \\
\hline & Hypocrea lixii BHU162 & $99 \%$ & JN604838.1 \\
\hline & Hypocrea lixii DLY1202 & $99 \%$ & HQ259304.1 \\
\hline & Hypocrea lixii T18-1 & $99 \%$ & EU744189.1 \\
\hline
\end{tabular}


2). However, it was observed that it maintains the viability of the Trichoderma spp. spores. Increasing temperature from 15 to $24^{\circ} \mathrm{C}$ led to an increase on the growth rates of Trichoderma, followed by a plateau. Optimum temperature for mycelial growth was observed between 24 and $28^{\circ} \mathrm{C}$. Strains ID11C and ID11D were found to show the highest growth characteristics in all tested temperatures (from 4 to $32^{\circ} \mathrm{C}$ ). In contrast, it was noted that ID7C strains exhibited the lowest growth level.

Temperature is considered as one of the most important parameters of biocontrol activity of Trichoderma spp [10]. In biocontrol organisms, the presences of tolerance against to temperature fluctuations are important parameters for the maintainability of life of the organism in extreme environments. The common incubation temperature for fungi growth such as Trichoderma sp., Fusarium sp., Penicillium sp. and Graphium sp. is $30^{\circ} \mathrm{C}$ [20]. and researchers also reported that none of the Trichoderma species grew at or above $40^{\circ} \mathrm{C}$. Therefore it could be concluded that time and incubation temperature were two effective criteria on the sporulation [14]. Some isolated Trichoderma strains from the higher altitude (2000-3500 m) of Garhwal Himalayan region in India presented similar results with previous reports [21]. In this study, Trichoderma spp. strains were revealed to exhibit the ideal growth at $24^{\circ} \mathrm{C}$ and $28^{\circ} \mathrm{C}$, however, the maximum temperature for Trichoderma spp. growth was examined at $32{ }^{\circ} \mathrm{C}$ when incubated on Tryptic Soy Agar under $4{ }^{\circ} \mathrm{C}$ conditions. The fungus was able to grow normally, characterized with heavily induced sporulation within three weeks of the incubation. Induction of sporulation via exposure to low temperatures appeared to be one of the strategies for survival of these species in extreme cold environments such as at 4 to $5^{\circ} \mathrm{C}$.

Trichoderma spp. spores were found to show heat tolerance at a certain range of temperature values $\left(45-75^{\circ} \mathrm{C}\right)$ after 10 min exposure (Table 2 ). In the heat tolerance test of this study, although all strains of Trichoderma spp. were detected to be able to germinate spores at the range of 45 to $65^{\circ} \mathrm{C}$, only three strains (ID11D, ID4A and ID4B) were observed to be able to protect the vitality of spores at $75^{\circ} \mathrm{C}$. Kucuk and Kivanc [22] indicated that 6 strains out of 7 isolates germinated at $75^{\circ} \mathrm{C}$. This result indicated that Trichoderma spp. spores are heat-tolerant for a certain period of time at a range of 45 to $75^{\circ} \mathrm{C}$. As Trichoderma spp. is well accepted being a potential and ecofriendly biological control agent by the community, it is necessary to grow it at suitable conditions before it could be used against to other soil borne plant pathogens or for commercial purposes. In this regard, heat tolerance of Trichoderma spp. spores is very important to maintain the viability during storage and after formulation processes.

Table 2. Radial growth of Trichoderma spp. at different temperatures on PDA medium for 48 hours and heat tolerance of fungi spores (cfu/mL).

\begin{tabular}{|c|c|c|c|c|c|c|c|c|c|}
\hline \multirow[t]{2}{*}{$\begin{array}{l}\text { Stra in } \\
\text { No }\end{array}$} & \multicolumn{5}{|c|}{ Incubation of temperature $\left({ }^{\circ} \mathrm{C}\right)$ and radial growth $(\mathrm{cm})$} & \multicolumn{4}{|c|}{ Heat $\left({ }^{\circ} \mathrm{C}\right)$ tolerance of spore $(10 \mathrm{~min})$} \\
\hline & 15 & 20 & 24 & 28 & 32 & 45 & 55 & 65 & 75 \\
\hline ID4A & 3.5 & 4.2 & 7.5 & 7.3 & 2.0 & $\geq 10^{3}$ & $\geq 10^{3}$ & $\geq 10^{3}$ & $2 \times 10^{2}$ \\
\hline ID4B & 2.5 & 3.7 & 5.2 & 6.0 & 2.0 & $\geq 10^{3}$ & $\geq 10^{3}$ & $\geq 10^{3}$ & $3 \times 10^{2}$ \\
\hline ID6B & 3.7 & 4.1 & 6.2 & 7.0 & 2.0 & $\geq 10^{3}$ & $\geq 10^{3}$ & $\geq 10^{3}$ & -* \\
\hline ID7C & 3.5 & 4.5 & 5.5 & 4.0 & 1.5 & $\geq 10^{3}$ & $\geq 10^{3}$ & $\geq 10^{3}$ & - \\
\hline ID9A & 3.5 & 4.2 & 6.8 & 7.0 & 2.0 & $\geq 10^{3}$ & $\geq 10^{3}$ & $\geq 10^{3}$ & - \\
\hline ID11C & 4.0 & 5.1 & 7.0 & 9.0 & 3.5 & $\geq 10^{3}$ & $\geq 10^{3}$ & $\geq 10^{3}$ & - \\
\hline ID11D & 4.0 & 5.3 & 8.5 & 9.0 & 3.5 & $\geq 10^{3}$ & $\geq 10^{3}$ & $\geq 10^{3}$ & $10^{2}$ \\
\hline ID17E & 4.0 & 5.1 & 5.5 & 7.0 & 3.0 & $\geq 10^{3}$ & $\geq 10^{3}$ & $\geq 10^{3}$ & - \\
\hline ID20G & 3.9 & 5.5 & 8.5 & 6.0 & 3.0 & $\geq 10^{3}$ & $\geq 10^{3}$ & $\geq 10^{3}$ & - \\
\hline $\begin{array}{l}K \cup E N \\
1585\end{array}$ & 3.5 & 3.0 & 8.0 & 6.0 & 3.0 & $\geq 10^{3}$ & $\geq 10^{3}$ & $\geq 10^{3}$ & - \\
\hline
\end{tabular}


Since optimization of the bio-control agents has vital importance, the best growth temperature and sporulation time were determined for the isolated strains in present work. The strain ID17E was found to have some growth parameters like commercial strain KUEN 1585 and no generated spore was detected under test conditions (Table 3). The highest number of spore was obtained from the strains ID9A, ID11C and ID11D at $28^{\circ} \mathrm{C}$ on day15, sporulation capacity of the strains were marked similar at 15, 20 and $24^{\circ} \mathrm{C}$ however, $28^{\circ} \mathrm{C}$ was significantly different in terms of strain's sporulation ability. The best incubation time and temperature was determined on day 15 at $28^{\circ} \mathrm{C}$ for Trichoderma spp. strains.

It is notorious notion that Trichoderma spp. species are effective against various gram positive and negative bacterial species [17]. In the present study, we analyzed that whether our isolated strains have anti-microbial activity or not. Ethyl acetate extract of Trichoderma spp. isolates were found to display antibacterial activity but not antifungal activity (Table 4). All extracts were detected to show antibacterial activity against Vibrio sp., S. marcescens, L. monocytogenes, B. cereus and B. subtilis except for ID17E and ID20G. The ID17E extract was observed to effective against to human pathogen $S$. aureus and the other strains' (ID4A, ID4B and ID6B) extracts were effective for M. smegmatis a causative agent of tuberculosis. These results indicate that the exercised strains are effective against bacterial plant pathogens. It was shown that $T$. harzianum and $T$. atroviride have produced some kind of antibiotics by other studies

Table 3. Spore production of Trichoderma spp. at different time intervals and in different temperatures (cfu/mL).

\begin{tabular}{|c|c|c|c|c|c|}
\hline Strain No & Days & $\begin{array}{l}\text { Incubation Tem- } \\
\text { peratures and } \\
\text { viable spores/ } \\
\mathrm{mL}\end{array}$ & & & \\
\hline & & $15^{\circ} \mathrm{C}$ & $20^{\circ} \mathrm{C}$ & $24^{\circ} \mathrm{C}$ & $28^{\circ} \mathrm{C}$ \\
\hline \multirow[t]{2}{*}{ ID4A } & 7 & $-*$ & $8.60 \times 10^{7}$ & $1.79 \times 10^{8}$ & $3.01 \times 10^{8}$ \\
\hline & 15 & $1.81 \times 10^{7}$ & $2.73 \times 10^{8}$ & $2.78 \times 10^{8}$ & $5.73 \times 10^{8}$ \\
\hline \multirow[t]{2}{*}{ ID4B } & 7 & - & $1.00 \times 10^{8}$ & $1.22 \times 10^{8}$ & $1.95 \times 10^{8}$ \\
\hline & 15 & $2.53 \times 10^{7}$ & $2.63 \times 10^{8}$ & $1.63 \times 10^{8}$ & $3.59 \times 10^{8}$ \\
\hline \multirow[t]{2}{*}{ ID6B } & 7 & - & $3.91 \times 10^{7}$ & $1.70 \times 10^{8}$ & $7.53 \times 10^{7}$ \\
\hline & 15 & $2.31 \times 10^{7}$ & $2.06 \times 10^{8}$ & $3.65 \times 10^{8}$ & $6.78 \times 10^{8}$ \\
\hline \multirow[t]{2}{*}{ ID7C } & 7 & - & $6.00 \times 10^{7}$ & $4.30 \times 10^{6}$ & $8.50 \times 10^{8}$ \\
\hline & 15 & $2.75 \times 10^{7}$ & $6.10 \times 10^{8}$ & $1.20 \times 10^{8}$ & $3.20 \times 10^{8}$ \\
\hline \multirow[t]{2}{*}{ ID9A } & 7 & - & $1.30 \times 10^{8}$ & $2.49 \times 10^{8}$ & $3.28 \times 10^{8}$ \\
\hline & 15 & $2.13 \times 10^{7}$ & $1.81 \times 10^{8}$ & $5.77 \times 10^{8}$ & $3.36 \times 10^{9}$ \\
\hline \multirow[t]{2}{*}{ ID11C } & 7 & - & $2.32 \times 10^{8}$ & $5.60 \times 10^{6}$ & $1.10 \times 10^{8}$ \\
\hline & 15 & $1.63 \times 10^{7}$ & $6.10 \times 10^{8}$ & $6.50 \times 10^{8}$ & $7.70 \times 10^{8}$ \\
\hline \multirow[t]{2}{*}{ ID11D } & 7 & - & $3.41 \times 10^{8}$ & $2.01 \times 10^{8}$ & $3.59 \times 10^{8}$ \\
\hline & 15 & $1.63 \times 10^{8}$ & $4.06 \times 10^{8}$ & $4.53 \times 10^{8}$ & $5.37 \times 10^{8}$ \\
\hline \multirow[t]{2}{*}{ ID17E } & 7 & - & - & - & - \\
\hline & 15 & - & - & - & - \\
\hline \multirow[t]{2}{*}{ ID20G } & 7 & - & $2.68 \times 10^{8}$ & $1.76 \times 10^{8}$ & $2.95 \times 10^{8}$ \\
\hline & 15 & $1.41 \times 10^{7}$ & $2.82 \times 10^{8}$ & $1.41 \times 10^{8}$ & $2.94 \times 10^{7}$ \\
\hline \multirow[t]{2}{*}{ KUEN 1585} & 7 & - & - & $1.78 \times 10^{7}$ & $1.26 \times 10^{7}$ \\
\hline & 15 & $4.06 \times 10^{6}$ & $4.94 \times 10^{6}$ & $5.03 \times 10^{7}$ & $2.43 \times 10^{8}$ \\
\hline
\end{tabular}

*- No growth 
Table 4. Inhibition zone (mm) of Trichoderma spp. fermentation broth extracts against some microorganisms.

\begin{tabular}{|c|c|c|c|c|c|c|c|c|c|c|c|c|c|}
\hline & ID4A & ID4B & ID6B & ID7C & ID9A & ID11C & ID11D & ID17E & ID20G & KUEN & ET.AS. & DMSO & Ant. \\
\hline & & & & & & & & & & 1585 & & & \\
\hline Ec & - & - & - & - & - & - & - & - & - & - & - & - & 10 \\
\hline $\mathrm{Pv}$ & - & - & - & - & - & - & - & - & - & - & - & - & 18 \\
\hline Ss & - & - & - & - & - & - & - & - & - & - & - & - & 18 \\
\hline Vs & 12 & 12 & 10 & 10 & 10 & 11 & 10 & 6 & 7 & 8 & 8 & - & 10 \\
\hline $\mathrm{Sm}$ & 12 & 12 & 11 & 10 & 10 & 11 & 10 & - & 6 & 7 & 7 & - & 10 \\
\hline $\mathrm{Kp}$ & - & - & - & - & - & - & - & - & - & - & - & - & 18 \\
\hline Yp & - & - & - & - & - & - & - & - & - & - & - & - & 18 \\
\hline $\mathrm{Pa}$ & - & - & - & - & - & - & - & - & - & - & - & - & 18 \\
\hline Sa & - & - & 6 & - & - & - & 6 & 15 & - & - & - & - & 35 \\
\hline Ef & - & - & - & - & - & - & - & - & - & - & - & - & 10 \\
\hline Lm & 8 & 7 & 6,5 & - & 6 & 6 & 6 & - & 6 & 6 & - & - & 10 \\
\hline $\mathrm{Bc}$ & 10 & 9 & 6 & - & 6 & 7 & 6 & 7 & - & - & - & - & 15 \\
\hline Bs & 8 & 7 & - & - & 6 & 6 & - & 9 & - & - & - & - & 20 \\
\hline $\mathrm{Ca}$ & - & - & - & - & - & - & - & - & - & - & - & - & $25 *$ \\
\hline $\mathrm{Ct}$ & - & - & - & - & - & - & - & - & - & - & - & - & $25^{*}$ \\
\hline Sc & - & - & - & - & - & - & - & - & - & - & - & - & $>25^{*}$ \\
\hline Ms & 17 & 14 & 10 & - & - & - & - & - & - & - & 8 & 6 & $35^{* *}$ \\
\hline$A n$ & - & - & - & - & - & - & - & - & - & - & - & - & ND \\
\hline Bcin & - & - & - & - & - & - & - & - & - & - & - & - & ND \\
\hline Rs & - & - & - & - & - & - & - & - & - & - & - & - & ND \\
\hline
\end{tabular}

Ec: E. coli ATCC25922, Pv: P. vulgaris, Ss: Salmonella sp., Vs: Vibrio sp., Sm: S. marcescens, Kp: K. pneumonia ATCC13883, Yp: Y. pseudotuberculosis ATCC 911, Pa: P. aeruginosa ATCC43288, Sa: S. aureus ATCC25923, Ef: E. faecalis ATCC29212, Lm: L. monocytogenes ATCC43251, Bc: B. cereus 709 ROMA, Bs: B. subtilis ATCC6633, Ca: C. albicans ATCC60193, Ct: C. tropicalis ATCC13803, Sc: S. cerevisiae RSKK251, Ms: M. smegmatis ATCC607, An: A. niger RSKK4017, Bcin: B. cinerea, Rs: R. solani AG3, (-); no effect, , KUEN 1585; T. harzianum KUEN 1585, ET.AS: Ethyl acetate, DMSO: Dimethyl sulfoxide, Ant.: Antibiotics, ND: Not determined, *: fluconazole **: Streptomycin.

[15]. When T. harzianum strains analyzed for their antagonistic activity, the isolates were found to be effective at various concentrations against to many bacterial species (S. aureus, E. coli, Proteus and Klebsiella) [23]. On the other hand, antimicrobial activities of 317 Basidiomycetes isolates were screened against nine human pathogens and the most susceptible micro-organism were reported as B. subtilis [24], which is very identical to our results. Tarus et al. [25] demonstrated that T. harzianum secondary metabolites (i.e. trisol, 6-phenyl prion and sorbicilin) were effective against to pathogen fungi of tea plants (Armillaria mella, Mucor and Nematospora corylii). That compounds (especially 6-phenyl prion) were found to be effective against an array of microorganisms (Paecilomyces vericoti, Penicilium notatum, Nematospora coryli, Bacillus brevis, B. subtilis, Sercinia lutea and Enterobacter dissolvens) with either their antibacterial and or antifungal activities. Liouane et al. [26] were reported that the analysed extract exhibited an intriguing antibacterial activity against to all tested bacteria except for the gram-negative $E$. coli and $P$. aeruginosa, but no antifungal activity was detected for the extracts. In our study, T. harzianum was found to show very high antagonistic activity against $A$. terreus and $A$. fumigatus. Clinical bacterial isolates of $S$. aureus and $E$. coli were found to be sensitive to T. harzianum extract. 
Table 5. Effect of Trichoderma spp. at day 4, 7 and 15 on in-vitro growth inhibition of some fungi through Dual Plate Culture Technique.

\begin{tabular}{|c|c|c|c|c|c|c|c|c|c|}
\hline \multirow[t]{2}{*}{$\begin{array}{l}\text { Strains } \\
\text { No }\end{array}$} & \multicolumn{9}{|c|}{ Growth range inhibition some of fungi (\%) } \\
\hline & Days & Rs & Bcin & $\mathrm{Ssc}$ & An & Af & $\mathrm{Bb}$ & If & $\mathrm{Ma}$ \\
\hline \multirow[t]{3}{*}{ ID4A } & 4 & 30 & 49 & 67 & 23 & 8 & 29 & 2 & 9 \\
\hline & 7 & 70 & 61 & 70 & 73 & 17 & 62 & 25 & 26 \\
\hline & 15 & 64 & 59 & 69 & 73 & 50 & 83 & 51 & 59 \\
\hline \multirow[t]{3}{*}{ ID4B } & 4 & 1 & 48 & 58 & 8 & 0 & 3 & 0 & 3 \\
\hline & 7 & 33 & 58 & 58 & 72 & 14 & 33 & 20 & 33 \\
\hline & 15 & 63 & 56 & 58 & 77 & 52 & 63 & 46 & 63 \\
\hline \multirow[t]{3}{*}{ ID6B } & 4 & 16 & 57 & 64 & 8 & 4 & 3 & 1 & 3 \\
\hline & 7 & 56 & 61 & 68 & 71 & 20 & 35 & 23 & 35 \\
\hline & 15 & 64 & 62 & 69 & 74 & 52 & 63 & 50 & 63 \\
\hline \multirow[t]{3}{*}{ ID7C } & 4 & 23 & 56 & 68 & 0 & 8 & 6 & 2 & 6 \\
\hline & 7 & 54 & 61 & 71 & 68 & 27 & 41 & 25 & 41 \\
\hline & 15 & 64 & 78 & 72 & 71 & 58 & 68 & 50 & 68 \\
\hline \multirow[t]{3}{*}{ ID9A } & 4 & 15 & 56 & 61 & 15 & 13 & 12 & 1 & 12 \\
\hline & 7 & 40 & 62 & 67 & 77 & 33 & 44 & 32 & 44 \\
\hline & 15 & 67 & 78 & 68 & 77 & 60 & 68 & 55 & 68 \\
\hline \multirow[t]{3}{*}{ ID11C } & 4 & 59 & 66 & 66 & 8 & 17 & 17 & 14 & 17 \\
\hline & 7 & 70 & 68 & 75 & 73 & 43 & 45 & 36 & 45 \\
\hline & 15 & 75 & 78 & 75 & 72 & 66 & 70 & 64 & 70 \\
\hline \multirow[t]{3}{*}{ ID11D } & 4 & 55 & 73 & 71 & 23 & 17 & 13 & 8 & 13 \\
\hline & 7 & 68 & 81 & 75 & 74 & 37 & 47 & 36 & 47 \\
\hline & 15 & 69 & 83 & 78 & 74 & 66 & 70 & 64 & 70 \\
\hline \multirow[t]{3}{*}{ ID17E } & 4 & 45 & 68 & 72 & 26 & 13 & 17 & 2 & 17 \\
\hline & 7 & 68 & 71 & 74 & 71 & 37 & 56 & 34 & 56 \\
\hline & 15 & 77 & 70 & 76 & 72 & 62 & 77 & 64 & 77 \\
\hline \multirow[t]{3}{*}{ ID20G } & 4 & 39 & 69 & 68 & 15 & 17 & 12 & 11 & 12 \\
\hline & 7 & 67 & 74 & 76 & 76 & 47 & 55 & 39 & 55 \\
\hline & 15 & 75 & 78 & 79 & 78 & 68 & 76 & 66 & 76 \\
\hline \multirow[t]{3}{*}{$\begin{array}{l}K \cup E N \\
1585\end{array}$} & 4 & 25 & 58 & 66 & 8 & 8 & 11 & 2 & 11 \\
\hline & 7 & 58 & 63 & 69 & 70 & 24 & 46 & 30 & 46 \\
\hline & 15 & 71 & 57 & 69 & 71 & 58 & 70 & 50 & 70 \\
\hline
\end{tabular}

Rs: R. solani (AG3), Bcin: B. cinerea, Sc: S. sclerotiorum, As: A. flavus, An: A. niger, Bb: B. bassiana ARSEF8664, Is: I. fumosorosea ARSEF8333, Ma: M. anisopliae ARSEF8433. 
In dual culture test, isolates of Trichoderma spp. showed variable effects against to other tested fungi. All Trichoderma spp. strains have high inhibition activities against plant pathogen strain B. cinerea, S. sclerotiorum and R. solani (AG3) (Table 5). Trichoderma spp. showed inhibition on tested fungi with a significant difference. There was not significant difference between day $7^{\text {th }}$ and $15^{\text {th }}$ (mean rank 26.39 and 29.34) but there was a significant difference between day 4 and other days (mean rank 44.77). In dual culture of Trichoderma-R. solani (plant pathogen) the inhibition was detected between $63 \%$ and $77 \%$ (Table 5). The best inhibition values were calculated as $77 \%, 75 \%$ and $69 \%$ for strain ID17E, ID20G and ID11D, respectively. In dual culture of Trichoderma - B. cinerea (plant pathogen), inhibition was determined between $56 \%$ and $83 \%$. The best inhibition values were calculated as $83 \%$ for ID11D and 78\% for ID20G, ID11C, ID7C and ID9A. In dual culture of Trichoderma - S. sclerotium (plant pathogen), inhibition was determined between $58 \%$ and $79 \%$. The best inhibitory strains were observed as ID20G, ID11D, ID17E and ID11C (79-75\%). In Trichoderma - A. niger and A. flavus (opportunist human pathogen) dual cultures inhibition percentages were calculated as $68 \%-78 \%$ and $50 \%-68 \%$, respectively. The best effective strains against to $A$. niger, were determined as ID9A (77\%) and ID2OG (78\%). The majority of Trichoderma isolates were found not to have significant effects on entomopathogenic fungi of $I$. fumosorosea, B. bassiana and M. anisopliae. Trichoderma spp. isolates were found to inhibit the growth of plant and human pathogens strongly, but there was no observed inhibition on insect pathogens. Therefore it is suggested that Trichoderma harzianum strains can be used either against to plant pathogens or in combination with insect pathogens in the environment safely as a biocontrol agent. Based on this knowledge, the analyzed isolates of Trichoderma spp. can be classified into 2 distinct groups based on their biocontrol capacity. The first group consists ID11C, ID11D, ID17E and ID20G, were true effective as potential bio-control agents. The second group consists ID4A, ID4B, ID6A, ID7C, ID9A, were effected the activities of tested pathogenic fungi but can not be categorized as good biocontrol agents in this study.
Antal et al. [27] reported that, 14 of Trichoderma spp. strains were identified as T. atroviride, $T$. harzianum and $T$. viride out of 360 . It was stated that these strains had good growth parameters at $5^{\circ} \mathrm{C}$, and inhibitory effects against $R$. solani and $F$. oxysporum in dual culture at $10^{\circ} \mathrm{C}$. Soil amendment with formulated Trichoderma spp. proved to be effective in controlling Sclerotium rolfsii, the causative agent for seedling disease of many crops and many researchers reported antagonistic activity of Trichoderma spp. isolates against plant pathogens especially against fungal ones such as Rhizoctonia solani and Sclerotium rolfsii [28]. Lone et al. [29] reported that $T$. harzianum isolated from the rhizosphere of Juglans regia L., caused inhibition the growth of A. niger by $75 \%, C$. spherospermum by $72.2 \%$ and $F$. oxysporum by $25 \%$. Isolated Trichoderma spp. from chickpea rhizosphere and root endophytic region, 7 isolates were found to show the highest (83.3\%) inhibition percentage out of ten isolates tested against Rhizoctonia bataticola [30]. It was determined that Trichoderma spp. had a significant effect against entomopathogenic biocontrol strains of $B$. bassiana, I. fumosorosea and M. anisopliae (Table 5). Due to the rapid growth of Trichoderma spp. strains, it was observed that the strains limited growth area of entomopathogens, showed vertical growth instead of radial growth and blocked the contact between Trichoderma spp. and entomopathogenic strain. In a report of Lopez and Orduz [31] entomopathogenic fungus, M. anisopliae (strain M-137), or the antagonist fungus, $T$. viride (strain T-26) or a combination of both entomopathogenic and antagonist fungi were applied to control $A$. cephalotes nests. The mortality of nests was found as $100 \%$ with $M$. anisopliae and the combined fungal treatment, and $80 \%$ mortality in the treatment with $T$. viride. Combined application of entomopathogens (B. bassiana, $M$. anisopliae and Paecilomyces fumosoroseus) with mycoparasites (Clonostachys spp., T. harzianum and Lecanicillium lecanii) did not influence their biological control efficacy in vivo, although the reisolation success of entomopathogens could be significantly reduced, especially from smaller insect species according to Krauss et al. [32]. Our results also supported these data and it was concluded that there is no effect of co-application of Trichoderma 
spp. strains with entomopathogens. Trichoderma spp. strain ID4B, ID11D and ID20G were found not to generate spores when tested to produce volatile metabolites (Table 6). All Trichoderma spp. strains were detected to produce volatile metabolite having effect in reducing sclerotia and radial growth of $S$. sclerotiorum.

In a report, volatile and non-volatile compounds produced from Trichoderma spp., T. saturnisporum, T. harzianum, $T$. viride, $T$. reesei were studied against Colletotrichum capsici. The volatile compounds produced from all the selected Trichoderma species were found to show 30 to $67 \%$ inhibition of $C$. capsici [33]. Approximately 250 volatile organic compounds have been identified from fungi up to know and Trichoderma spp. species are known to produce numerous volatile organic compounds [34]. Mohiddin et al. [35] reported that 6 isolated T. viride inhibited sclerotia production of S. rolfsii (48\%) and S. sclerotium (78\%) and developed mycelia by $40 \%$. Fungal volatile organic compounds are important in the functioning of both atmospheric and soil ecosystems [36]. When twelve isolates were tested for the production of volatile and non-volatile metabolites, it was found that some of these compounds (Isobutyric acid, 1.8-Cineole and 6-Pentyl-a-pyrone) showed antifungal and antibacterial activity and in addition to the biocontrol strategies [37]. In our study, Trichoderma spp. produced some volatile metabolites, inhibited production of sclerotia and growth of pathogens at the same time. The best effective strains were determined as ID6B, ID11C, ID11D and ID20G in terms of volatile compound production.

Captan is a broad-spectrum fungicide that belongs to the phthalimide chemical family. There are number of fungicides that contain copper hydroxide and Cuprenax is one of them. Mancozeb (Dikozin) contains zinc and manganese ethylene bisdithiocarbamate [38]. All of these fungicides are used for greenhouse and/or nursery of plants depends on the formulation. Trichoderma spp. strains were tested against to various concentrations of different groups of fungicide (Captan (Phthalimide), Dikozin (dithiocarbamate) and Cuprenax (inorganic)) and the highest tolerance was detected against to Dikozin and the lowest to the Captan (Table 7). It was not determined that there is a significant difference among Cuprenax concentrations (2.5, 5, $10 \mathrm{mg} \mathrm{mL}^{-1}$ ) on the growth rate of Trichoderma spp.

Table 6. Evaluation of volatile metabolites produced by Trichoderma spp. isolates against mycelial growth and spore production in Sclerotonia sclerotium.

\begin{tabular}{lllll}
\hline Trichoderma Strain No & \multicolumn{2}{c}{ Trichoderma spp. } & \multicolumn{2}{c}{ Sclerotonia sclerotium } \\
\hline & Growth & Spore production & Growth & Sclerotia production \\
\hline ID4A & ++ & ++ & ++ & $*-$ \\
\hline ID4B & ++ & - & ++ & - \\
\hline ID6B & +++ & + & + & - \\
\hline ID7C & +++ & ++ & ++ & - \\
\hline ID9A & +++ & ++ & ++ & - \\
\hline ID11C & +++ & ++ & + & - \\
\hline
\end{tabular}

$(+)$; low, (++); good, (+++); very good, (-); negative, *; no sporulation

\begin{tabular}{lllll}
\hline ID11D & +++ & - & + & - \\
\hline ID17E & ++ & - & ++ & - \\
\hline ID20G & +++ & - & + & - \\
\hline KUEN 1585 & ++ & - & & +++ \\
\hline Negative control & +++ & ++ & +++ \\
\hline Sclerotonia control & & & +++ & + \\
\hline
\end{tabular}


Table 7. The growth zone of Trichoderma spp. on PDA medium containing fungisit (on day 7, mm).

\begin{tabular}{|c|c|c|c|c|c|c|c|c|c|}
\hline \multirow[t]{2}{*}{$\begin{array}{l}\text { Strain } \\
\text { No }\end{array}$} & \multicolumn{3}{|c|}{$\begin{array}{l}\text { Capta } \mathrm{n} \\
\left(\mathrm{mg} \mathrm{mL}^{-1}\right)\end{array}$} & \multicolumn{3}{|c|}{$\begin{array}{l}\text { Dikozin } \\
\left(\mathrm{mg} \mathrm{mL}^{-1}\right)\end{array}$} & \multicolumn{3}{|c|}{$\begin{array}{l}\text { Cuprenax } \\
\left(\mathrm{mg} \mathrm{mL}^{-1}\right)\end{array}$} \\
\hline & 2.5 & 5 & 10 & 2.5 & 5 & 10 & 2.5 & 5 & 10 \\
\hline ID4A & 40 & 20 & 14 & 85 & 85 & 39 & 35 & 35 & 40 \\
\hline ID4B & 40 & 20 & 14 & 85 & 85 & 40 & 35 & 34 & 38 \\
\hline ID6B & 38 & 21 & 19 & 85 & 85 & 35 & 36 & 30 & 29 \\
\hline ID7C & 38 & 20 & 18 & 85 & 85 & 20 & 30 & 30 & 29 \\
\hline ID9A & 28 & 22 & 18 & 85 & 85 & 30 & 34 & 30 & 30 \\
\hline ID11C & 48 & 20 & 19 & 85 & 85 & 80 & 50 & 45 & 40 \\
\hline ID11D & 35 & 35 & 19 & 85 & 85 & 85 & 42 & 40 & 40 \\
\hline ID17E & 28 & 15 & 5 & 85 & 60 & 50 & 39 & 34 & 30 \\
\hline ID20G & 20 & 12 & 9 & 85 & 70 & 40 & 20 & 17 & 15 \\
\hline $\begin{array}{l}\text { K U E N } \\
1585\end{array}$ & 75 & 35 & 25 & 85 & 85 & 20 & 35 & 35 & 30 \\
\hline
\end{tabular}

*The zone diameter of the control groups were $85 \mathrm{~mm}$ at day 7.

strains. However, there was a significant difference among $2.5 \mathrm{mg} \mathrm{mL}^{-1}$ and other doses of Captan and among $10 \mathrm{mg} \mathrm{mL}^{-1}$ and other doses of Dikozin. It was observed that $10 \mathrm{mg} \mathrm{mL}^{-1}$ of Captan inhibited the growth of Trichoderma spp. strains by $80 \%$. Dikozin and Cuprenax inhibited the growth at the same concentration by $50 \%$ and $62 \%$, respectively. Trichoderma spp. was found to be the most sensitive to Captan, Propiconazole and Tebuconazole in our study. Among tested fungicides the most resistant strains were determined as ID11C and ID11D, the most susceptible strain was determined as ID20G. Thiram, Mancozeb, Tebuconzole were found to be the best effective fungicides and the least effective ones were reported as Pyrocymidone and Captan on T. harzianum C52 spore germination in a previous study [39]. Khan and Shahzad [19] reported that $T$. harzianum were able to proliferate under the low doses of various fungicides (Benomly, Topsin-M, Carbendazim and Cuprocaffro). A similar report on T. harzianum's potential integration as a biological agent was reported by Saxena et al. [40]. The compatibility was assessed at different concentrations and the concentration of Carbendazim, Metalaxyl, Captan, Mancozeb, Thiram and Nemacur were under the safe tolerance limit for T. harzianum whereas the corresponding values for T. virens were found as $40,1000,125,177,9$, and $700 \mu \mathrm{g} / \mathrm{mL}$, respectively according to Mohiddin and
Khan.[35] The in-vitro effect of 6 commonly used fungicides on the mycelial growth of Trichoderma harzianum PBT 23 were evaluated in another study and Captan, Thiram, Chlorothalonil and Copper hydroxide were reported compatible with the test antagonist up to $100 \mu \mathrm{g} / \mathrm{mL}$, while Mancozeb was compatible with up to $250 \mu \mathrm{g} / \mathrm{mL}$. It is reported that these affect the growth of test antagonist adversely [40]. Parab et al. [41] studied the sensitivity of T. harzianum against to different fungicides and the results indicated that all systemic fungicides were found to inhibit the growth of $T$. harzianum completely whereas Zineb, Copper hydroxide, Mancozeb and copper oxychloride were found safe for the growth of T. harzianum.

Based on our results, although there was a reduction in growth rate, used and over dose concentrations of the strain of interest were detected to sustain growth. The strains ID11C, ID11D and ID20G were characterized as potential biocontrol agents that did not affect the vitality.

\section{CONCLUSION}

With this study an attempt has been made to grow different species of Trichoderma spp. at various temperatures, with their antifungal and antibacterial activity in order to reveal all 
the relevant and favorable parameters. The Trichoderma spp. species inhibits the growth of pathogens by releasing antibiotics and other volatile compounds that are harmful to the pathogens. We showed that mycelia growth inhibition affects Trichoderma's volatile organic compounds without direct physical contact between the pathogen and fungus. The temperature is an important parameter for the growth of pathogen and biocontrol agent because it affects spore germination, mycelial growth and competitive saprophytic ability. It is important using Trichoderma spp. as a potential bio-control agent in different geographic regions, because strains maintain their spore vitality at a temperature range of $4-75^{\circ} \mathrm{C}$ and can grow at $15-37^{\circ} \mathrm{C}$. This characteristic provides the adaptation of bio-control agents to temperatures at application fields and sustainability of the adapted strains. Considering the reproductive properties, spore production, fungisit tolerance and pathogen inhibition it can be concluded that ID11D and ID11C might be better bio-control agents. Identifying biocontrol agents and understanding the mechanisms underlying the antagonistic effect of Trichoderma spp. on plant pathogens are important in creating effective and safe bio-control strategies. Possible mechanisms of antagonism employed by Trichoderma spp. includes nutrient and niche competitions, antibiosis by producing volatile components and non-volatile antibiotics that are inhibitory against a range of soil-borne fungi, as well as parasitism. Different soil isolates of Trichoderma spp. can variable in their ability to fight against to different fungal pathogens. Therefore, enlightening the effects of new biocontrol agents to provide disease control is important.

\section{ACKNOWLEDGEMENTS}

The study was supported by a grant of Recep Tayyip Erdogan University scientific research projects unit (Project No: 2012.102.03.3). We thank Assos. Prof. Dr. Sevim A., (for providing entomopathogenic fungi), Kırşehir Ahi Evran University, Prof. Dr. Özer G. (for R. solani AG3) Abant İzzet Baysal University, Prof. Dr. Yanar Y. (for S. sclerotiorum) Gazi Osman Paşa University, Prof. Dr. Karakaya, A., (for B. cinerea) Ankara University for their valuable help. Commercial strain T. harzianum KUEN 1585 were obtained from Simbiyotek Biyolojik Ürünler San. ve Tic. A.Ş.

\section{References}

1. Y. Elad, Biological control of foliar pathogens by means of Trichoderma harzianum and potential modes of action, Crop Prot., 19 (2000) 709-714.

2. E. Demirci, E. Dane, C. Eken, In vitro antagonistic activity of fungi isolated from sclerotia on potato tubers against Rhizoctonia solani, Turk. J. Biol., 35 (2011) 457-462.

3. M.A. Rifai, Revision of the genus Trichoderma, Myc. Papers., 116 (19691) 56.

4. N. Sadfi-Zouaoui, S. Châabani, M. Rouaissi, A. Hedi, M. Hajlaoui, A. Boudabous, Analysis of the diversity of Trichoderma spp. in soil horizons using digested ITS regions, Ann. Microbiol., 59 (2009) 459-463.

5. D.M. Geiser, J.C. Frisvad, J.W. Taylor, Evolutionary relationships in Aspergillus section Fumigati inferred from partial $\beta$-tubulin and hydrophobin DNA sequences. Mycologia, (1998) 831-845.

6. W.J. Janisiewicz, L. Korsten, Biological control of postharvest diseases of fruits, Annu. Rev. Phytopathol., 40 (2002) 411-441.

7. M. Verma, KB. Satinder, R.D. Tyagi, Bench-scale fermentation of Trichoderma viride on wastewater sludge: rheology, lytic enzymes and biocontrol activity, Enzyme Microb. Tech., 41 (2007) 764-771.

8. R.M. Saleh, Screening and production of antibacterial compound from Trichoderma spp. against humanpathogenic bacteria, Afr. J. Microbiol. Res., 5 (2011) 1619-1628.

9. J. Locke, J. Marois, G. Papavizas, Biological control of Fusarium wilt of greenhouse-grown chrysanthemums. Plant Dis. 69 (1985) 167-169.

10. L. Kredics, Z. Antal, L. Manczinger, Influence of environmental parameters on Trichoderma strains with biocontrol potential, Food. Technol. Biotechnol., 41 (2003) 37-42.

11. S.A. Karaoglu, S. Ulker, Isolation, identification and seasonal distribution of soilborne fungi in tea growing areas of Iyidere-Ikizdere vicinity (Rize-Turkey), J. Basic. Microbiol., 46 (2006) 208-218.

12. S. Kanematsu, S. Naito, Genetic characterization of rhizoctonia solani ag-2-3 by analyzing restriction fragment length polymorphisms of nuclear ribosomal DNA internal transcribed spacers, Jap. J. Phytopathol., 61 (1995) 18-21.

13. K.J. Martin, P.T. Rygiewicz, Fungal-specific PCR primers developed for analysis of the ITS region of environmental DNA extracts, BMC Microbiol., 5 (2005) 28-28.

14. A. Singh, Influence of temperature, $\mathrm{pH}$ and media for growth and sporulation of Trichoderma atroviride and its shelf life study in different carrier based formulation, J. Plant. Dis. Sci., 6 (2011) 32-34.

15. Á. Keszler, E. Forgács, L. Kótai, Separation and identification of volatile components in the fermentation broth of Trichoderma atroviride by solid-phase extraction and gas chromatographymass spectrometry, J. Chromatogr. Sci. 38 (2000) 421-424.

16. S. Siddiquee, U.K. Yusuf, K. Hossain, S. Jahan, In vitro studies on the potential Trichoderma harzianum for antagonistic properties against Ganoderma boninense, J. Food Agric. Environ., 7 (2009) 970-976. 
17. J.A. Vizcaino, S. Luis, B. Angela, F. Vicente, S. Gutierrez M.R. Hermosa, E. Monte, Screening of antimicrobial activities in Trichoderma isolates representing three Trichoderma sections, Mycol. Res., 109 (2005) 13971406.

18. G.L. Woods, A.B.E. Barbara, S.C. Patricia, Susceptibility testing of Mycobacteria, nocardiae, and other aerobic actinomycetes; Approved Standard 2nd ed. Wayne (2003) Pennsylvania.

19. M.O. Khan, S. Shahzad, Screening of Trichoderma species for tolerance to fungicides, Pak. J. Bot., 39 (2007) 945-951.

20. V. Santos, V.R. Linardi, Biodegradation of phenol by a filamentous fungi isolated from industrial effluentsidentification and degradation potential, Process. Biochem., 39 (2004) 1001-1006.

21. B.B. Joshi, M.P. Vishwakarma, D. Bahukhandi, R.P. Bhatt, Studies on strains of Trichoderma spp. from high altitude of Garhwal Himalayan region, J. Environ. Biol., 33 (2012) 843-847.

22. C. Kucuk, M. Kivanc, Isolation of Trichoderma spp. and determination of their antifungal, biochemical and physiological features, Turk J. Biol., 27 (2003) 247253.

23. F.B.H. Khethr, S. Ammar, D. Saidana, M. Daami, J. Chriaa, K. Liouane, M.A. Mahjoub, A.N. Helal, Z. Mighri, Chemical composition, antibacterial and antifungal activities of Trichoderma spp. growing in Tunisia, Ann. Microbiol., 58 (2008) 303-308.

24. I. Suay, F. Arenal, F.J. Asensio, A. Basilio, M.A. Cabello, M.T. Diez, J.B. Garcia, A.G. Del Val, J. Gorrochategui, Screening of basidiomycetes for antimicrobial activities, Antonie van Leeuwenhoek, 78 (2000) 129 139.

25. P. Tarus, C.C. Lang'at-Thoruwa, A.W. Wanyonyi, Bioactive metabolites from Trichoderma harzianum and Trichoderma longibrachiatum, Bull. Chem. Soc. Ethiop., 17 (2003) 185-190.

26. K. Liouane, D. Saidana, S. Ammar, Chemical composition and antimicrobial activity of methanolic extract of Trichoderma sp. growing wild in Tunisia. J. Essent. Oil Bear. PI., 12 (2009) 531-540.

27. Z. Antal, L. Manczinger, G. Szakacs, R. Tengerdy, L. Ferenczy, Colony growth, in vitro antagonism and secretion of extracellular enzymes in cold-tolerant strains of Trichoderma species, Mycol. Res., 104 (2000) 545-549.

28. B. Ngo, D. Vu, D. Tran, Analyze antagonist effects of Trichoderma spp. for controlling southern stem rot caused by Sclerotium rolfsii on peanut, Plant Prot., 1 (2006) 12-14

29. M.A. Lone, M.R. Wani, S.A. Sheikh, Antagonistic potentiality of Trichoderma harzianum against Cladosporium spherospermum, Aspergillus niger and Fusarium oxysporum, J. Biol. Agric. Healthc., 2 (2012) 72-76.
30. G.A. Veena, R. Eswara, R. Bhasakara, Pathogenicity tests and evaluation of efficacy of fungicides against Rhizoctonia bataticola, the causal agent of dry root rot of chickpea, Int. J. Appl. Biol. Pharm., 5 (2014) 283-287.

31. E. Lopez, S. Orduz, Metarhizium anisopliae and Trichoderma viride for control of nests of the fungusgrowing ant, Atta cephalotes, Biol. Control, 27 (2003) 194-200.

32. U. Krauss, E. Hidalgo, C. Arroyo, Interaction between the entomopathogens Beauveria bassiana, Metarhizium anisopliae and Paecilomyces fumosoroseus and the mycoparasites Clonostachys spp., Trichoderma harzianum and Lecanicillium lecanii, Biocontrol. Sci. Techn., 14 (2004) 331-346.

33. P. Ajith, N. Lakshmidevi, Effect of volatile and nonvolatile compounds from Trichoderma spp. against Colletotrichum capsici incitant of anthracnose on bell peppers, Nat. Sci., 8 (2010) 265-269.

34. N. Stoppacher, B. Kluger, S. Zeilinger, R. Krska, R. Schuhmacher, Identification and profiling of volatile metabolites of the biocontrol fungus Trichoderma atroviride by HS-SPME-GC-MS, J. Microbiol. Methods., 1 (2010) 187-193.

35. F. Mohiddin, M. Khan, Tolerance of fungal and bacterial biocontrol agents to six pesticides commonly used in the control of soil borne plant pathogens, Afr. J. Agric. Res., 8 (2013) 5331-5334.

36. M. Shaik, Non-volatile and volatile metabolites of antagonistic Trichoderma against collar rot pathogen of mentha arvensis, Int. J. Pharm., 2 (2011) 56-58.

37. S.U. Morath, R. Hung, JW. Bennett, Fungal volatile organic compounds: a review with emphasis on their biotechnological potential, Fungal Biol. Rev., 26 (2012) 73-83

38. H.H. Oruc, Fungicides. InTech: Chapter 17, Fungicides and their effects on animals, (2010) 349-362.

39. K. McLean, J. Hunt, A. Stewart, S. Zydenbos, Compatibility of the biocontrol agent Trichoderma harzianum C52 with selected fungicides, In: Proceedings of The New Zealand Plant Protection Conference, (2001) New Zealand Plant Protection Society.

40. D. Saxena, A. Tewari, D. Rai, The in vitro effect of some commonly used fungicides, insecticides and herbicides for their compatibility with Trichoderma harzianum PBT23, World Appl. Sci. J., 31 (2014) 444448.

41. P. Parab, M. Diwakar, U. Sawant, J. Kadam, Exploration of Trichoderma harzianum as antagonist against Fusarium spp. causing damping off and root rot disease and its sensitivity to different fungicides, J. Plant Dis. Sci., 4 (2009) 52-56. 